\title{
Ecological-Genetic Studies and Conservation of Endemic Quercus sideroxyla (Trel.) in Central Mexico
}

\author{
Cecilia Alfonso-Corrado', Ricardo Clark-Tapia', Alejandro Monsalvo-Reyes ${ }^{2}$, \\ Carlos Rosas-Osorio², Gabriel González-Adame1, Francisco Naranjo-Luna1, \\ Crystian-Sadiel Venegas-Barrera ${ }^{3}$, Jorge E. Campos ${ }^{2 *}$ \\ ${ }^{1}$ Instituto de Estudios Ambientales, Universidad de la Sierra Juárez, Ixtlán de Juárez, México \\ ${ }^{2}$ Laboratorio de Bioquímica Molecular-Unidad de Biotecnología y Prototipos (UBIPRO), Fes-IZTACALA, UNAM, \\ Tlalnepantla, México \\ ${ }^{3}$ InstitutoTecnológico de Ciudad Victoria, Ciudad Victoria, México \\ Email: ${ }^{\text {jcampos@unam.mx }}$
}

Received 16 May 2014; revised 17 June 2014; accepted 30 June 2014

Copyright (C) 2014 by authors and Scientific Research Publishing Inc. This work is licensed under the Creative Commons Attribution International License (CC BY). http://creativecommons.org/licenses/by/4.0/

(c) (i) Open Access

\section{Abstract}

This study examines the distribution, ecology and genetic diversity of Quercus sideroxyla Humb. Bonpl, with an emphasis on its conservation on the Natural Protected Area of Sierra Fría in North Central Mexico. Twenty-nine locations were selected, and in each location, one plot of $1500 \mathrm{~m}^{2}$ was established. At every location, we obtained an abundance of $Q$. sideroxyla and a basal area for each individual tree, including geographical and climatological data. We used the Outlying Mean Index (OMI) to examine whether environmental conditions had a distributional effect on $Q$. sideroxyla populations and to obtain the static size population structure of the species. For the genetic analysis, we collected 18 adult individuals from each population, four polymorphic loci were used to estimate genetic diversity. $Q$. sideroxyla abundance was associated with narrow environmental conditions, especially when considering the topographical and meteorological environmental variables. The allelic richness value was 84 alleles ( 21 privatealleles), and the expected mean heterozygosity was $0.855 \pm \mathbf{0 . 0 0 9}$. The high vulnerability of the species to changes in the land use at the local scale and to global climatic changes increases the species' susceptibility to local disappearance.

\section{Keywords}

Ecology, Genetic Diversity, Local Conservation, Niche, Oaks

\footnotetext{
${ }^{*}$ Corresponding author.
} 


\section{Introduction}

Quercus L. is the largest genus of the Fagaceae family, containing approximately 500 species worldwide [1] Of these, 135 to 160 species of this oak are found in Mexico, with 106 of them being endemic [2], mostly in the Central and Southern regions of Mexico [3]. In Mexico, the genus is especially well represented because oak forests cover $9 \times 106$ ha of Mexico's temperate mountain territories [4]. However, few studies have been performed in Mexico regarding the ecology of the oak species, specifically the vulnerable or endemic species [5][7], or the genetic variability within these species [8]-[10]. An evaluation of the current status of these species is necessary, particularly in areas where human activities have caused reduction of the oak forests [5].

In Mexico, oak forests have provided a wide range of ecological and economic resources to human populations for centuries [3] [4]. Urbanization, agriculture, logging, livestock, charcoal production [4], and climatic changes [6] continue to negatively affect oak forest in Mexico. These impacts may necessitate the establishment of forest management practices that favour oaks, policed conservation areas, and restoration programs. A comprehensive understanding of the distribution and biology of oaks, especially for vulnerable and endemic species in the temperate forests in local areas of Mexico, may also be fundamental to their preservation [5] [11].

Quercus sideroxyla Humb. \& Bonpl., is an endemic species in the North forest of Mexico, it has a narrow distribution to cooler and wetter sites [12]. Major threats to the persistence of $Q$. sideroxyla populations include climatic change [6] habitat loss associated with land-use change towards farming and forestry industry. This species have been exploited since the 16th century to obtain firewood, charcoal for local uses and used for wood production in Mexico’s forestry industry. However, our knowledge about the ecology, genetic and how anthropogenic disturbance affect to the species is limited. Profound knowledge of $Q$. sideroxyla is very important for conservation biology, with the challenge being to develop strategies for working with local people in conservation programs and devising policies [13] [14], in effect, the local people must be made partners in conservation.

This idea has been applied most often in "traditional” settings, such as the "indigenous Mexican societies". In many cases, these societies feature strong conservation ethics and traditional ecological knowledge that allow people to create management and conservation actions linked to belief systems that are enforced by village consent and the authority of leaders [14]. The challenge now is how to create and propose similar systems to local people that occupy areas with natural forests but that do not live in traditional societies.

The Sierra Fría forest, located in the state of Aguascalientes, is an important oak forest in Central Mexico. Over the past 17 years programs that collaborate with locals have been established for the conservation of this forest. It was designated as local reserve in 1994, containing 17 species of oaks [15]. However, this forest was subject to intense degradation activities from 1930 to 1950 that included timber extraction, introduction of agriculture and grazing [16] [17].

Recently, studies to understand the ecology and genetics of the Sierra Fría's oak species has been undertaken, with a special emphasis on the development of conservation programs for vulnerable and endemic species, such as Q. eduardii, Q. grisea, Q. potosina and Q. sideroxyla [8]-[10]. Findings indicate that Q. sideroxyla is likely the most vulnerable oak species to climate change in the Sierra Fría forest. Preliminary observations indicate a fragmented distribution and reliance on specific climatic and edaphic conditions to survive. Models predict that climate change could reduce the distribution of this species by more than 35\% in Mexico [6].

The objectives of the present work were 1) to establish the distribution of Q. sideroxyla in the Sierra Fría, in Aguascalientes; 2) to determine the environmental variables most closely associated with the niche distribution of $Q$. sideroxyla; 3) to obtain the static size population structure of the species within the range of its distribution in the Sierra Fría; 4) to determine the genetic diversity within and among populations; 5) find correlations between demographical and genetic parameters; and 6) to provide recommendations for the conservation of $Q$. sideroxyla populations on the local scale.

\section{Experimental Section}

\subsection{Study Area}

This study was carried out in the Natural Protected Area of Sierra Fría (21 $52^{\prime} 44^{\prime \prime N}, 102^{\circ} 22^{\prime} 44^{\prime \prime} \mathrm{W}$ and $23^{\circ} 31^{\prime} 17^{\prime \prime N}$, $102^{\circ} 50^{\prime} 53^{\prime \prime} \mathrm{W}$ ), in the state of Aguascalientes, central Mexico (Figure 1). Its average temperature is $14.5^{\circ} \mathrm{C}$, with a median annual rainfall of $651.4 \mathrm{~mm}$. The vegetation consists mainly of temperate oak, oak-juniper or pine-oak forests at altitudes ranging from 1900 to 2800 m.a.s.l. 

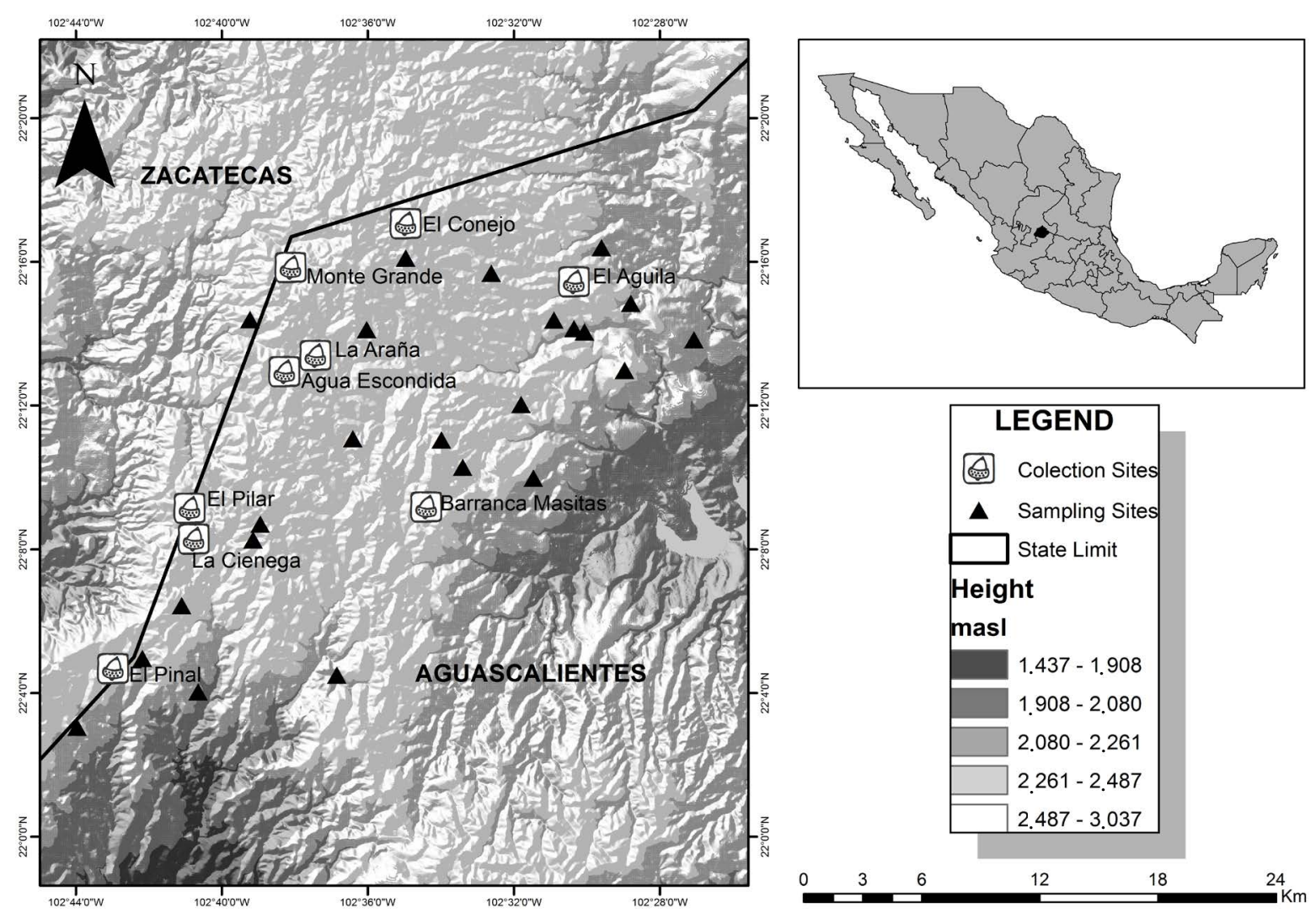

Figure 1. Location of Q. sideroxyla populations in the Sierra Fría protected landscape area in Aguascalientes, Central Mexico.

\subsection{Study Species}

Quercus sideroxyla Humb. \& Bonpl., or red oak (Lobatae), have trunk heights varying between 5 and 20 m, although some trees of this species reach $30 \mathrm{~m}$ in height. It is an endemic species with narrow distribution to cooler and wetter areas in the Northeastern (Nuevo León, Tamaulipas), Northwestern (Sonora, Chihuahua, Durango) and North-Central forests (Aguascalientes, Zacatecas, San Luis Potosí, Jalisco) of Mexico. Flowering occurs in May and fructification from September to November [15]. Its regeneration occurs by sexual reproduction (acorn production) and clonal growth (root suckers). However, field observations of these individuals showed that the origin of these individuals is mainly by clonal growth in more than $98 \%$ of cases. No acorn production was recorded from 2006 to 2010 in any sites with the exception of one study site (La Ciénega). However, despite acorn production, annual surveys from 2007 to 2010 recorded no recruitment of new individuals in the field at this site.

\subsection{Distribution and Ecology of Q. sideroxyla}

29 sites were selected in the oak forests, in each site one plot of $1500 \mathrm{~m}^{2}$ was established. Field data obtained inside each plot included: 1) latitude and longitude, recorded with a handheld GPS (Garmin 2.01), 2) altitude and slope orientation and 3) abundance and basal area.

To test the association of environmental variations with the abundance of $Q$. sideroxyla on 29 sites selected, we performed the Outlying Mean Index (OMI), implemented in ADE-4 software [18], relating 13 variables with the abundance: 1) altitude (Alt), 2) Annual Average Temperature (AAT), 3) Monthly Average of Minimal Temperature (MMinT), 4) Minimal Temperature of Maximal Temperature in warmer Quarter (MiTMxTWQ), 5) Maximal Temperature of Maximal Temperatures in Colder Quarter (MaTMxTWQ), 6) Minimal Temperature of Minimal Temperatures in Warmer Quarter (MinTMiWC), 7) Maximal Temperature of Minimal Temperatures in Colder Quarter (MaTMiCQ), 8) Temperature Standard Deviation (TSD), 9) Maximum precipitation of driest 
quarter (MPPDQ), 10) Annual maximum precipitation (TMaP), 11) Annual minimal precipitation (TMiP), 12) Minimum precipitation of wettest quarter (MPPWQ) and 13) Monthly precipitation (MP). The last 12 variables were derived from WorldClim climatic layers.

The analysis used two matrices: a botanic matrix, containing the abundance of the species (rows) on 29 sites (columns), and an environmental matrix, containing 13 environmental variables (rows, one topographic and twelve climatic) on the same 29 sites (columns). The environmental matrix was analyzed with PCA to ordinate the sites in function of environmental variables, though the correlation matrix. The inertia variance of the average environmental conditions used by the specie, was used to derive three parameters: 1) Outlying Mean Index (marginality index), which measures the distance between the mean environmental conditions used by species and the mean environmental conditions of the sampling area; 2) tolerance index (niche breadth) that described the variance of niche across the measured environmental variables and 3) residual tolerance, variance not explained. We used a Monte Carlo test to compare the observed marginality of specie versus the distribution of 10,000 random permutation values, under the null hypothesis that its environment does not affect the species occurrence. Permutation values lower than 500 were interpreted, as the species marginality index is statistically different from average environmental conditions available $(\mathrm{P}=0.05)$. Using field data, we employed ArcGIS 9.3 [19] software to map the geographical distribution of Q. sideroxyla in the Sierra Fría. Records were used to test for uniform slope orientation of oaks on each population with a Rayleigh's test (R) using circular statistics Oriana for Windows, version 1.03 [20].

Basal area data was used to obtain the population structure of $Q$. sideroxyla in each site and each individual was classified in six stage classes. Plants up to $5 \mathrm{~cm}^{2}$ in basal area represented class 1, ranging from 5.01 to 35 $\mathrm{cm}^{2}$, class 2. For reproductive individuals, basal area intervals were $35.1-150 \mathrm{~cm}^{2}$ for class $3,150.01-400 \mathrm{~cm}^{2}$ for class 4, $400-800 \mathrm{~cm}^{2}$ for class 5 , and $>800 \mathrm{~cm}^{2}$ for class 6 . In addition, one-way Kruskal-Wallis ANOVA on ranks were tests and a Tukey multiple comparisons test were used to evaluate the frequency of individuals among sites and stage class.

\subsection{Genetic Diversity}

In August 2007 we selected nine populations of Q. sideroxyla along its distributional range in the Sierra Fría (Figure 1). In each population eighteen adult individuals were sampled to estimate main parameters according to [21]. At one site, only six adults were found. Each individual was collected every $50 \mathrm{~m}$ along a $900 \mathrm{~m}$ transect where Q. sideroxyla was found. A total of 150 individuals of the species were collected. Samples were kept in plastic bags and immediately stored in liquid nitrogen, transported to the laboratory and stored at $-70^{\circ} \mathrm{C}$.

Genomic DNA was extracted from $0.1 \mathrm{~g}$ of foliar tissue, using the Qiagen Plant Minikit according to the manufacturer's instructions. Twelve primers were tested, six developed by [22], and six by [23]. Only four (quru-GA-0C11, quru-GA-0C19, quru-GA-E09 and quru-GA-1F07) were polymorphic for Q. sideroxyla.

PCR reactions were performed in $25 \mu \mathrm{l}$ containing $1 \times$ buffer $(500 \mathrm{mM} \mathrm{KCl}$ and $200 \mathrm{mM}$ Tris- $\mathrm{HCl}, \mathrm{pH}$ 8.4) (Invitrogen), $4 \mathrm{mM}$ of $\mathrm{MgCl}_{2}$ (Invitrogen), $10 \mathrm{ng}$ of DNA template, $10 \mathrm{mM}$ of each dNTP, (Pharmacia), $0.4 \mu \mathrm{M}$ of reverse and forward primers, $2 \mu \mathrm{g}$ of BSA and $0.5 \mathrm{U}$ of Taq DNA polymerase (Invitrogen). Amplification reactions were carried out using a PTC-100 MJ Research thermal cycler. PCR cycling conditions were 5 min at $95^{\circ} \mathrm{C}, 30$ cycles of $94^{\circ} \mathrm{C}$ for $10 \mathrm{~s}$, annealing according to the different primer temperatures $\left(\mathrm{Tm}^{\circ} \mathrm{C}\right)$ for $10 \mathrm{~s}$ and extension at $72^{\circ} \mathrm{C}$ for $10 \mathrm{~s}$, with a final 8 min extension at $72^{\circ} \mathrm{C}$. PCR products were analysed by capillary electrophoresis using an ABI PRISM-3100 Genetic Analyzer and genotypes were scored using GENESCAN version 3.5 (Applied Biosystems, Foster City, CA, USA).

GenAlEx version 6.5 beta 3 [24] was used to estimate number of alleles (Ao), number of private alleles (Ap), observed heterozygosis (HO), and expected heterozygosis (HE). GENEPOP version 4.1 [25] was used to test for deviation from Hardy-Weinberg equilibrium, according to Fisher's procedure, with combined probabilities from exact tests by the Markov chain method with 10,000 dememorization steps and 1000 batches (Iteration per batch $=1000$ ). Also, linkage disequilibrium was assayed between pairs of loci, we used likelihood-ratio test, and the empirical distribution was obtained by a permutation procedure according to [26]. MICRO-CHECKER software [27] was used to test the presence either of null alleles, stuttering or large allele dropout. We used the four loci for the regional-scale analyses in order to calculate null alleles in each population. All populations showed null allele and were coded as missing data. Also, an analysis of molecular variance (AMOVA) was done using the 
program GenoDive version 2.0b24 [28]. The significance of these values was tested using a non-parametric permutation according to [29], and also gene flow $\left(\mathrm{N}_{\mathrm{e}} \mathrm{m}\right)$ was estimated according to [30].

Demographic parameters were analysed by the Pearson Correlative Coefficient (PCC) between demographic variables as the number of individuals in each population $(\mathrm{N})$, number of individuals in each population on stage class (Ns) and genetic parameters as expected heterozigosity, observed heterozigosity, genetic flow $\left(\mathrm{N}_{\mathrm{e}} \mathrm{m}\right)$, number of observed alleles (Ao) and number of private alleles (Ap), where positive values reflect direct incidence, negative values reflect inversely proportional relations and values close to zero reflects no relationship.

\section{Results}

\subsection{Distribution and Ecology of Quercus sideroxyla}

In the Sierra Fría, this species had a fragmented distribution and was only found in nine of the 29 sites sampled (Figure 1). Q. sideroxyla was distributed in complex damp slopes located mostly along the Northern orientation $(\mathrm{R}=0.895, \mathrm{P}=0.005$ ) and between 2471 (El Águila) and 2852 (Monte Grande) m.a.s.l. The Outlying Mean Index (OMI) suggested that $Q$. sideroxyla was significantly influenced by meteorological and geographical variables $(\mathrm{P}=0.008)$, with lower tolerance index and residual tolerance values (Table 1$)$. In the Outlying index, the first two axes account for $99.8 \%$ of data variation, with the annual maximum precipitation (TMaP) and the minimal temperatures in warmer quarters (MinTMiWC) accounting for the major variation on the first axis, and the annual minimal precipitation (TMiP) in rainy months being responsible for the principal variation on the second axis (Figure 2). Abundance of Q. sideroxyla was associated to sites with higher minimal and maximal temperatures than the average on the 29 samples (11 and $17.6 \mathrm{~mm}$, respectively).

Total number of individuals ranged from 30 at Barranca Macitas to 145 at La Araña and La Ciénega (Figure $3)$. In general, the greatest number of individuals belonged to size stage class 1. Exceptions were El Pilar, Agua Escondida and El Águila. A population size structure analysis of Q. sideroxyla showed that four populations (Barranca Macitas, El Pinal, La Araña and La Ciénega) had inverted J distribution patterns, while the other five showed different patterns.

El Águila and El Pilar sites showed scarce evidence of recent recruitment (either clonal or by seeds), with a low number of plants in size stage classes 1, 2 and 3, whereas at Monte Grande and Agua Escondida, an equal number of individuals in all size stage classes were found. El Conejo presented a considerable large number of individuals (82) in size stage class 1, suggesting a successful recruitment process for this site, also with a considerable number of individuals (50) found in size stage class 4 (see Figure 3). Additionally, significant differences in the abundance within the size stage classes were observed among the sites $(\mathrm{H}=8.65, \mathrm{P}=0.05)$. The only site with significant differences in the size stage class populations was Barranca Macitas, $(\mathrm{H}=9.690, \mathrm{P}=$ 0.001).

\subsection{Genetic Diversity}

The four microsatellite loci used in this study generated a total of 84 alleles across the 149 individuals. The genetic diversity across the populations is shown in Table 2. The number of alleles (Ao) ranged from 24 in Barranca Macitas to 49 in El Conejo (average $38.6 \pm 8.1$ ). A total of 21 number of private alleles (Ap) were found, ranging from 0 at Barranca Macitas and to 5 at El Conejo, and the average number of alleles found was $2.33 \pm$ 1.5. The global mean heterozygosity expected (HE) and heterozygosity observed (HO) values were $0.855 \pm$ 0.009 and $0.733 \pm 0.021$, respectively. A significant deviation from the Hardy-Weinberg equilibrium (HWE) was observed for the entire population, except at Barranca Macitas and Monte Grande (Table 2). No linkage disequilibrium was found for any loci or in any site. The average estimated value of FIS was $0.11(\mathrm{P}=0.001)$

Table 1. Niche parameters of Q. sideroxyla in 29 sites along Sierra Fría.

\begin{tabular}{ccccccccc}
\hline Species & Inertia & OMI & Tol & RTol & OMI $^{*}$ & Tol $^{*}$ & RTol $^{*}$ \\
\hline Q. sideroxyla & 8.086 & 5.248 & 1.994 & 0.844 & 64.9 & 24.7 & 10.4 \\
\hline
\end{tabular}

Inertia $=$ total variability, OMI = outlying mean index $(\%)$, Tol = tolerance index $(\%)$, RTol = residual tolerance $(\%),{ }^{*}$ OMI, Values with asterisk represent the percentages of variability corresponding to a specific statistic, $\mathrm{P}=$ frequency based on number of random permutations (out of 1000 ) that yielded a higher value than the observed outlying mean index $(\mathrm{P}=0.05)$. 


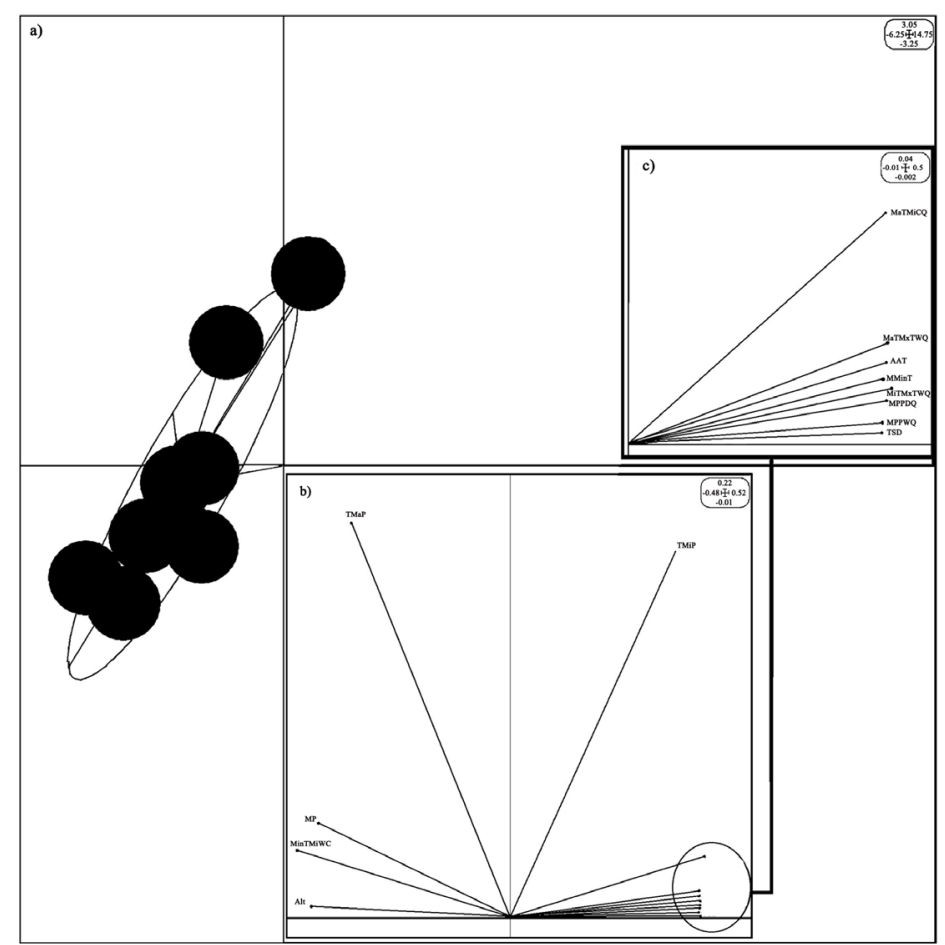

Figure 2. Ordination diagrams on the first two axes of outlying mean index analysis (OMI). (a) Niche position of Q. sideroxyla in 29 sites along Sierra Fría; (b) Canonical weights of the environmental variables; for the abbreviations of environmental variables, see data analysis.
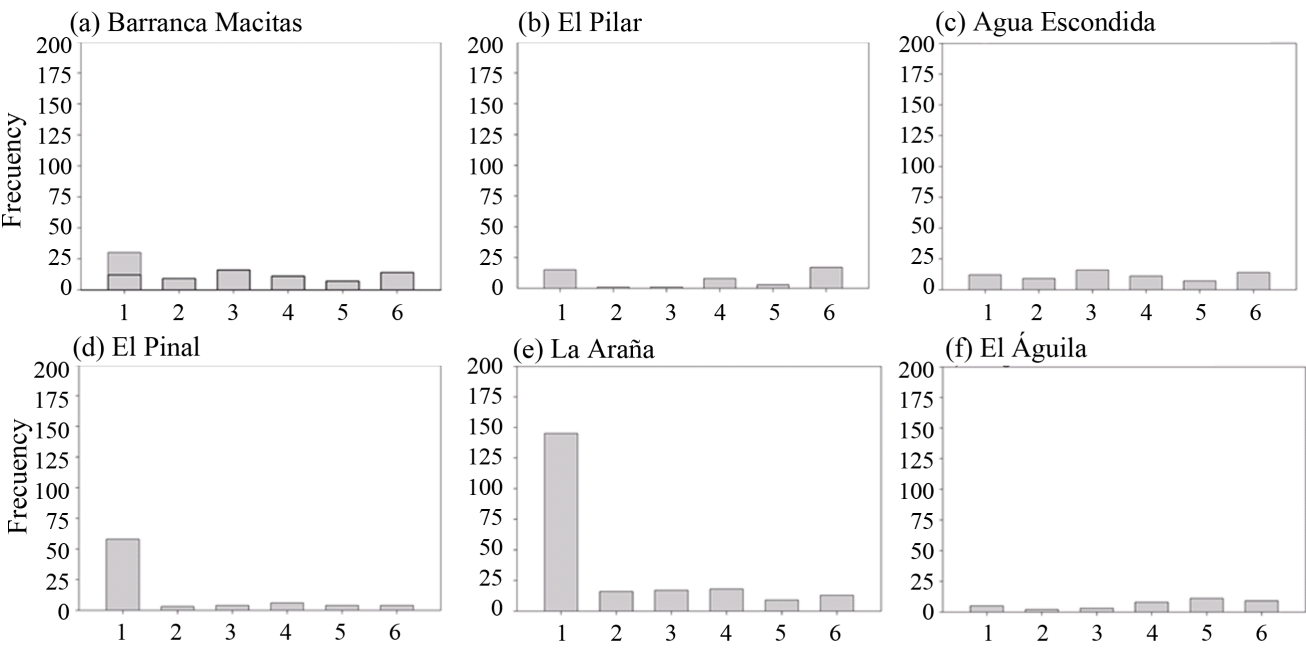

(f) El Águila
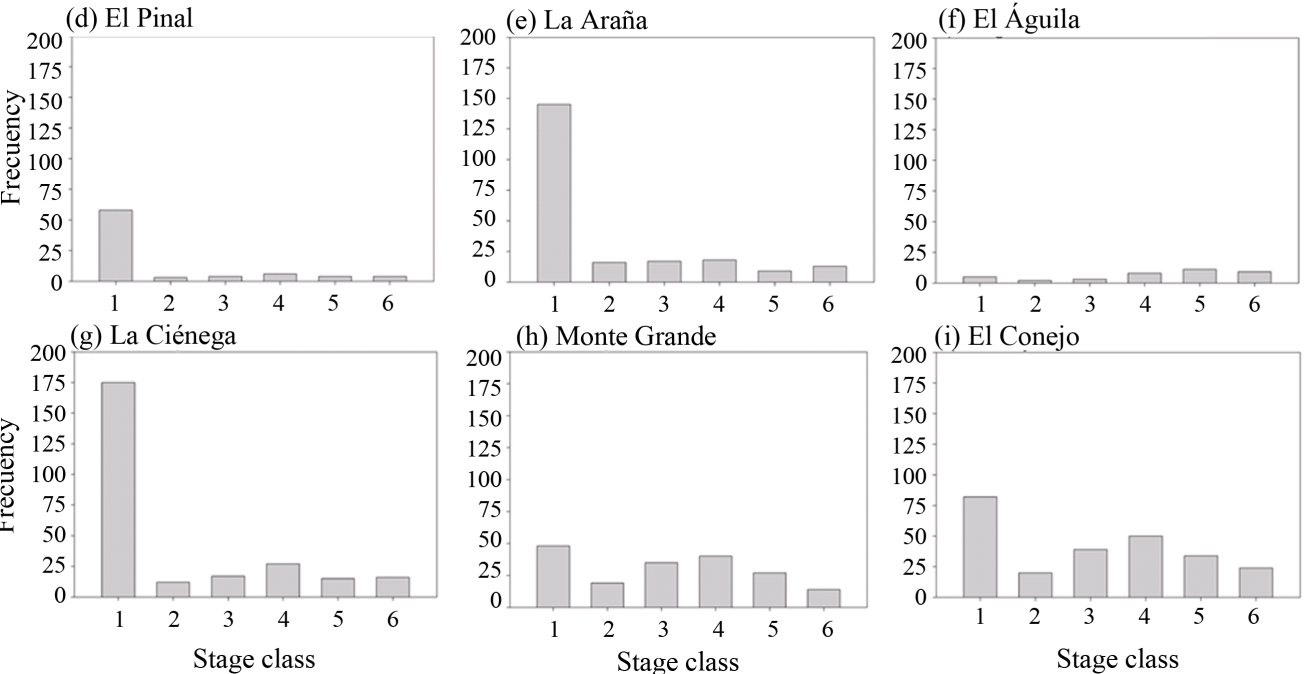

Figure 3. Static Size population structure of each populations of Sierra Fría, Aguascalientes. 
Table 2. Genetic diversity in the nine Q. sideroxyla sites.

\begin{tabular}{|c|c|c|c|c|c|}
\hline Population & Ao & Ap & $\mathrm{HO}$ & $\mathrm{HE}$ & HWE \\
\hline Barranca Macitas & 24 & 1 & $0.792 \pm 0.080$ & $0.767 \pm 0.020$ & n.s. \\
\hline El Pilar & 37 & 3 & $0.741 \pm 0.024$ & $0.846 \pm 0.013$ & ** \\
\hline Agua Escondida & 29 & 0 & $0.718 \pm 0.133$ & $0.826 \pm 0.026$ & ** \\
\hline El Pinal & 43 & 3 & $0.675 \pm 0.040$ & $0.869 \pm 0.011$ & *** \\
\hline La Araña & 40 & 3 & $0.713 \pm 0.042$ & $0.862 \pm 0.024$ & $* *$ \\
\hline El Águila & 36 & 1 & $0.692 \pm 0.058$ & $0.896 \pm 0.009$ & $* * *$ \\
\hline La Ciénega & 44 & 2 & $0.722 \pm 0.039$ & $0.871 \pm 0.008$ & $* *$ \\
\hline Monte Grande & 46 & 3 & $0.803 \pm 0.048$ & $0.851 \pm 0.041$ & n.s. \\
\hline El Conejo & 49 & 5 & $0.788 \pm 0.059$ & $0.896 \pm 0.009$ & ** \\
\hline Mean & $38.6 \pm 8.1$ & $2.33 \pm 1.5$ & $0.733 \pm 0.021$ & $0.855 \pm 0.009$ & ** \\
\hline
\end{tabular}

Ao - the total number of alleles detected, Ap—number of private alleles, HO — observed heterozygosis with standard error, HE- expected heterozygosis with standard error, HWE-Hardy-Weinberg equilibrium, $\mathrm{P}$ - Level of significance, ${ }^{*} \mathrm{P}<0.05,{ }^{* *} \mathrm{P}<0.01,{ }^{* * *} \mathrm{P}<0.001$.

for all sites. An ANOVA showed that $99.0 \%$ of the genetic variation was contained within the individuals of the populations, while only $1.0 \%$ occurred among the population. The global fixation index, FST, was 0.010 , which was highly significant $(\mathrm{P}=0.001)$, and the gene flow $\left(\mathrm{N}_{\mathrm{e}} \mathrm{m}\right)$ among populations was $4.43 \pm 0.53$.

Correlative analysis showed a major relationship between alleles observed in each population (Ao) and number of individuals in each population (PCC $=0.55)$, number of individuals on category $4(\mathrm{CCP}=0.56)$ and number of individuals on category five $(\mathrm{CCP}=0.52)$.

\section{Discussion}

\subsection{Distribution and Ecology of Quercus sideroxyla}

Q. sideroxyla presented a fragmented distribution in Sierra Fría forest, associated with specific conditions of orientation and altitudinal ranges. This pattern has been reported for this species in northern regions of Mexico [12], as well as for other species of oak [2] [31], where topographic and climatic factors have limited the distribution of those species. Poulos et al. [12] and [32] have suggested that Q. sideroxyla has evolved to survive and reproduce under a narrow range of specific climatic conditions.

According to the outlaying index, the annual maximum precipitation (TmaP), the annual minimal precipitation (TmiP), and the minimal temperatures in the warmer quarter months (MinTMiWC) were the principal factors affecting the abundance of $Q$. sideroxyla, suggesting an increased sensitivity, niche specialization and habitat selection in response to specific meteorological conditions. Similarly, [12] suggested that the species has specific climatological and physiological requirements, such as higher levels of photosynthesis, stomatal conductance, relative water content and water potential values, when compared with other Quercus species.

The climatic affinity, sensitivity and specificity of the Q. sideroxyla niche in Sierra Fría forest could be factors that affect its distribution and its permanence. Permanence rate scenarios indicate that this species is one of the most vulnerable species of oak in Mexico, with $35 \%$ of its current distribution presenting susceptibility to decrement [6]. Changes at the local scale can generate a reduction in population size or even local extinction.

In all of the study sites, size stage class 1 (which is primarily the result of clonal growth through root suckering) represented the regeneration of $Q$. sideroxyla and is likely due to the constant, intense grazing and logging that has occurred in the region since the 20th century. Demographic studies of Q. eduardii and Q. potosina in Sierra Fría forest support this assertion. In these cases, the clonal offspring remained connected for a long period of time to the parent tree, favouring the offspring, most likely by allowing the clones to recover from grazing and trampling [5] [16]. 
However, the different shapes found among the static population size structures of $Q$. sideroxyla may reflect the history of different intensive regimens of logging and grazing over the past 80 years in the Sierra Fría. Barranca Macitas, El Pinal, Agua Escondida and La Ciénega sites showed reverse J-shaped patterns that suggests a stable population with good recruitment and a low probability of death in the last size stage class [5] [33], also indicates populations of stable growth, with lower intensities of logging and grazing [5] [34].

This J-shape pattern was also found in the Q. eduardii and Q. potosina populations in disturbed (logging and grazing) and undisturbed sites in the Sierra Fría. In both species, the population's growth rates were above or equal to unity for both types of sites, suggesting that the populations were stable [5] suggested the possibility that Q. eduardii can protect itself by adjusting its vital rates, resulting in fewer disturbances. This scenario appears similar to what was observed for Barranca Macitas, El Pinal, Agua Escondida and La Ciénega sites.

However, in El Águila and El Pilar sites little evidence of recent recruitment (either clonal or by seed) was found, with a low number of plants in size stage classes 1, 2 and 3, only adult size class individuals create a demographic effect in which only the largest trees still exist, suggesting a more severe and historical human impact from logging and grazing. A similar scenario was found in Bertholletia excelsa by [34], where high harvesting intensity over time led to a size class structure characterized by a large number of cohorts and little regeneration.

However, variation in the middle and large size classes of trees would be expected to depend upon the intensity of the disturbance, as suggested by [35] studies on Araucaria angustifolia, showing that the presence of small individuals depends on anthropogenic history factors, such as the recovery time since abandonment, or the expected impact of logging on the proportion of small individuals in a population. Our results actually support Souza's findings, with similar patterns being found in Monte Grande and Agua Escondida. In these two sites, it appeared that the main regeneration event was clonal growth because contemporary logging and grazing activities were reduced, or even absent, compared with historical records. This is contrasting to the El Conejo site, where logging is more intense now than in the past, and the middle size class is absent in the population's size structure, which is a typical demographic effect produced by logging [36] [37].

\subsection{Genetic Diversity}

The average allele diversity obtained in the four loci used for $Q$. sideroxyla (Ao $=21 \pm 5.65$ ) was equal to or greater than those of the other oak species that were subjected to forest management, such as $Q$. suber $($ Ao $=$ $13.1 \pm 6.62)$ [38] and $Q$. petraea (Ao $=18.7 \pm 5.65)$ [39]. The diversity of $Q$. sideroxyla was also equal to or greater than those species that had been submitted to cattle or agriculture, such as $Q$. humboldtii (Ao $=13 \pm 8.5$ ) [40], and that of the complex of red oaks formed by Q. rubra, Q. shumardii and Q. palustris (Ao $=17.1 \pm 4.93$ ) [41]. Additionally, the species presented a high number of private alleles $(\mathrm{Ap}=21)$, with important implications for $Q$. sideroxyla from a local evolutionary perspective. The high number of private alleles could be the result of introgressive hybridization [42] or the constant interchange among neighboring populations. Regardless of the source, [43] noted the importance of the private alleles as a potential reservoir with adaptive capability. In addition to changes in unusual environmental conditions or anthropogenic stresses, if we consider the history of wood extraction [16], the vulnerability of $Q$. sideroxyla to climatic change [6] and the high sensibility and niche specificity of the species found in the present study, the private alleles might play an important role in the persistence of the species at the local scale.

Correlation analysis showed a narrow dependence of observed alleles and population size. Observed alleles are very sensitive to population size in Quercus species, recent studies show that endemic species have a minor number of alleles than other species [44] [45], also [21], showed that number of alleles are very sensitive and increase with sample size. We found a positive correlation in observed alleles with the whole population size, and we propose that observed allele number could be an indirect estimator of population's size useful in conservation programs.

The clonal regenerative capability of $Q$. sideroxyla allows the undisturbed preservation of genotypes, a phenomenon that was also found in Q. eduardii and Q. potosina in the study zone [5] [8]. These typical life histories could be responsible for the preservation of the genetic diversity of a species, despite the prolonged years of intensive extraction and the changes in soil use that have occurred in the Sierra Fría during the 20th century [16] [17], and could have served as a damping capability against earlier disturbances at the local scale [8] [40].

Heterozygosity values showed that the populations of $Q$. sideroxyla departed from the Hardy-Weinberg equilibrium, signifying that, for most sites (except Barranca Macitas and Monte Grande) a heterozygosis deficit were 
common (Table 2). Possible cause for this result could be inbreeding, as has been reported in other oak species in the Sierra Fría [10].

The gravity seed dispersal system of Q. sideroxyla, common in Sierra Fría oaks [8] [9], could be responsible for the formation of family groups. Family groups in oaks generally occur at short distances (less than 20 meters) from the progenitor tree [39]. For example, in Q. petraea [46], family groups could be identified by their genetic similarity and the spatial distribution among individuals. While these family groups had no significant effect on the population's genetic structure, heterozygosis deficit were detected. Heterozygosis deficit, combined with FIS value (0.11) in $Q$. sideroxyla indicated some degree of consanguinity, however, it is necessary to analyse the spatial genetic structure on a very fine scale to understand the distribution of family groups and clones that establish patterns of non-random pollination between individuals.

The full differentiation index of the population's genetic structure was low $(\mathrm{FST}=0.010)$ and abundant gene flow $\left(\mathrm{N}_{\mathrm{e}} \mathrm{m}=4.43\right)$ is indicative of populations that have not been founded recently, but are remnant populations of a once more widespread and perhaps more continues distribution, a pattern also found in other Sierra Fría oaks [8]-[10].

\section{Conclusions}

Q. sideroxyla populations are ecologically and genetically viable, presenting a large number of individuals and high values of genetic variation. These results under the general terms of Mexican Ecology Laws [47] could indicate that this species is not threatened or endangered. However, the changes in land use in Sierra Fría forest that have occurred since the last century, combined with the high climatic affinity, sensitivity, local niche specificity, and high vulnerability to global climate change of $Q$. sideroxyla strongly suggest that this species is highly susceptible to disappearance, at least at the local scale.

An extraordinary case is the Pinal site, which suffered a population decrease of $99.5 \%$ in 2013 . The potential reduction of this small population was caused by fungi that damaged the wood. The increased mortality of forest tree species is associated with climate change as well as interactions with other climate-mediated species, such as fungi [48]. For these reason, it is urgent to conserve the Mexican Quercus species at the local scale. Our suggestion is that the El Conejo, La Ciénegea, El Águila and Monte Grande sites be prioritized for conservation or employed for restoration of peripheral populations. These sites combine abundance of individuals with a high number of alleles and expected heterozygosis.

The conservation of oak species in Mexico is difficult due to the high level of species endemism [2], the presence of local ecological and genetic adaptations of species [5] [8] and, more particularly, government policies that are geared towards conservation and management at the local level, rather than on a more extensive level. The ecological-genetic studies that have been conducted for more than 10 years in the Sierra Fría have revealed unique biological aspects and needs in each oak species, with $Q$. sideroxyla being a strategic species for viable local conservation policies. The paradigms of conservation biology focus on local conservation efforts, in which people play key roles as active participants along with researchers and local governments [13] [14]. The next major step, is to integrate the social, scientific, and political interests, that can be accomplished with workshops, meetings, education, and community-based proposals, where interests converge for the common good and for the conservation and management of the oak species in the Sierra Fría, a reservoir of biodiversity and the most important forest in the state of Aguascalientes.

\section{Acknowledgements}

We thank to the community of Sierra Fría and to José Medina Flores from Instituto del MedioAmbiente del Estado de Aguascalientes for logistic support on fieldwork. Susana Valencia and Margarita de la Cerda help to identify this species. We are also grateful to Fanny Garvey provided helpful comments on a former version of this manuscript. Financial support was provided by CONAFOR-CONACYT (14074).

\section{References}

[1] Larsen, D.R. and Johnson, P.S. (1998) Linking the Ecology of Natural Oak Regeneration to Silviculture. Forest Ecology and Management, 106, 1-7. http://dx.doi.org/10.1016/S0378-1127(97)00233-8

[2] Valencia-Avalos, S. (2004) Diversidad del géneroQuercus (Fagaceae) en México. Revista de la Sociedad Botánica de México, 75, 33-53. 
[3] Nixon, K.C. (1998) El género Quercusen México. In: Ramamoorthy, T.P., Bye, R., Lot, A. and Fa, J., Eds., Diversidad biológica de México, Instituto de Biología, Universidad Nacional Autónoma de México, México D.F., 435-447.

[4] Challenger, A. (1998) Utilización y conservación de los ecosistemas terrestres de México, Pasado, Presente y Futuro. CONABIO-UNAM-SIERRA MADRE, México, D.F.

[5] Alfonso-Corrado, C., Clark-Tapia, R. and Mendoza, A. (2007) Demography and Management of Two Clonal Oaks: Quercus eduardii and Q. potosina (Fagaceae) in Central Mexico. Forest Ecology and Management, 251, $129-141$. http://dx.doi.org/10.1016/j.foreco.2006.11.004

[6] Gómez-Mendoza, L. and Arriaga, L. (2007) Modeling the Effect of Climate Change on the Distribution of Oak and Pine Species of Mexico. Conservation Biology, 21, 1545-1555. http://dx.doi.org/10.1111/j.1523-1739.2007.00814.x

[7] Olvera-Vargas, M., Figueroa-Rangel, B.L. and Vazquez-Lopez, J.M. (2010) Is There Environmental Differentiation in the Quercus Forests of West-Central Mexico? Plant Ecology, 211, 321-335. http://dx.doi.org/10.1007/s11258-010-9792-z

[8] Alfonso-Corrado, C., Esteban-Jiménez, R., Clark-Tapia, R., Piñero, D., Campos, J.E. and Mendoza, A. (2004) Clonal and Genetic Structure of Two Mexican Oaks: Quercus eduardii and Q. potosina (Fagaceae). Evolutionary Ecology, 18, 585-599. http://dx.doi.org/10.1007/s10682-004-5145-5

[9] Rosas-Osorio, J.C., Alfonso-Corrado, C., Monsalvo-Reyes, A., Clark-Tapia, R., Lira-Saade, R. and Campos-Contreras, J. (2010) The Genetic Variability of Quercus grisea Liebm, in the Sierra Fría of Aguascalientes, México. International Oak Journal, 21, 64-72.

[10] Gorgonio-Ramírez, M. (2012) Variabilidad y estructuragenética de Quercus eduardii (Fagaceae) en Sierra Fría, Aguascalientes. B.Sc. Thesis, Universidad de la Sierra Juárez, Ixtlán de Juárez.

[11] Zavala-Chávez, F. (1990) Los encinos mexicanos: Un recurso desaprovechado. Ciencia y Desarrollo, 95, 43-51.

[12] Poulos, H.M., Goodale, U.M. and Berlyn, G.P. (2007) Drought Response of Two Mexican Oak Species, Quercus lacely and Q. sideroxyla (Fagaceae), in Relation to Elevational Position. American Journal of Botany, 94, 809-818. http://dx.doi.org/10.3732/ajb.94.5.809

[13] Vera, P., Sasa, M., Encabo, S.I., Barba, E., Belda, E.J. and Monrós, J.S. (2011) Land Use and Biodiversity Congruences at Local Scale: Applications to Conservation Strategies. Biodiversity and Conservation, 20, 1287-1317. http://dx.doi.org/10.1007/s10531-011-0028-x

[14] Primack, R.B. (2012) A Primer of Conservation Biology. 5th Edition, Sinauer Associates, Sunderland, MA.

[15] de la Cerda, M. (1999) Encinos de Aguascalientes. Universidad Autónoma de Aguascalientes, Aguascalientes.

[16] Minnich, R., Sosa-Ramírez, J., Franco-Vizcaíno, E., Barry, W.J. and Siqueiros, M. (1994) Reconocimiento preliminar de la vegetación y de los impactos de lasactividades humanas en la Sierra Fría, Aguascalientes. Revista Investigación y Ciencia, 4, 23-29.

[17] Chapa-Bezanilla, D., Sosa-Ramírez, J. and de Alba-Ávila, A. (2008) Estudio multitemporal de los bosques de Sierra Fría, Aguascalientes, México. Maderas y Bosques, 14, 37-51.

[18] Thioulouse, J., Chessel, D., Dolédec, S. and Olivier, J.M. (1997) ADE4: A Multivariate Analysis and Graphical Display Software. Statistics and Computer, 7, 75-83. http://dx.doi.org/10.1023/A:1018513530268

[19] ESRI (1999) ArcView GIS. Version 3.2, Environmental Systems Research Institute, Inc., Redlands.

[20] Kovach (1994) Oriana for Windows. Version 1.03, Kovach Computing System, Wales.

[21] Pruett, C. and Wiener, K. (2008) The Effects of Sample Size in Population Genetic Diversity Estimates in Song Sparrows Melospiza melodía. Journal of Avian Biology, 39, 252-256. http://dx.doi.org/10.1111/j.0908-8857.2008.04094.x

[22] Steinkellner, S., Fluch, H., Turetschek, E., Lexer, C., Streiff, R., Kremer, K., Burg, J. and Glossl, C. (1997) Identification and Characterization of (GA/CT)n-Microsatellite Loci from Quercus petraea. Plant Molecular Biology, 33, 1093-1096. http://dx.doi.org/10.1023/A:1005736722794

[23] Aldrich, R.P., Micher, C.H., Sun, W. and Romero-Severson, T. (2002) Microsatellite Marker for Northern Red Oak (Fagaceae: Quercusrubra). Molecular Ecology Notes, 2, 472-474. http://dx.doi.org/10.1046/j.1471-8286.2002.00282.x

[24] Peakall, R. and Smouse, P.E. (2012) GenALEx 6.5: Genetic Analysis in Excel. Population Genetic Software for Teaching and Research—An Update. Bioinformatics, 28, 2537-2539. http://dx.doi.org/10.1093/bioinformatics/bts460

[25] Rousset, F. (2008) Genepop’007: A Complete Re-Implementation of the Genepop Software for Windows and Linux. Molecular Ecology Resources, 8, 103-106. http://dx.doi.org/10.1111/j.1471-8286.2007.01931.x

[26] Slatkin, M. and Excoffier, L. (1996) Testing for Linkage Disequilibrium in Genotypic Data Using the Expectation-Maximization Algorithm. Heredity, 76, 377-383. http://dx.doi.org/10.1038/hdy.1996.55

[27] Van Oosterhout, C., Hutchinson, W.F., Wilss, D.P.M. and Shipley, P. (2004) Micro-Checker: Software for Identifying and Correcting Genotyping Error in Microsatellite Data. Molecular Ecology, 4, 535-538. 
http://dx.doi.org/10.1111/j.1471-8286.2004.00684.x

[28] Meirmans, P.G. and Van Tienderen, P.H. (2004) GENOTYPE and GENODIVE: Two Programs for the Analysis of Genetic Diversity of Asexual Organisms. Molecular Ecolology Notes, 4, 792-794. http://dx.doi.org/10.1111/j.1471-8286.2004.00770.x

[29] Excoffier, L., Smouse, P.E. and Quattro, J.M. (1992) Analysis of Molecular Variance Inferred from Metric Distance DNA Haplotypes-Applications of Human Mitochondrial-DNA Restriction DATA. Genetics, 131, 479-491.

[30] Crow, J.F. and Aoki, K. (1984) Group Selection for a Polygenic Behavioral Trait: Estimating the Degree of Population Subdivision. Proceedings of the National Academy of Sciences of the United States of America, 81, 6073-6077. http://dx.doi.org/10.1073/pnas.81.19.6073

[31] Álvarez-Moctezuma, J.G., Ochoa-Gaona, S., de Jong, B.H.J. and Soto-Pinto, M.L. (1999) Hábitat y distribución de cincoespecies de Quercus (Fagaceae) en la Meseta Central de Chiapas. Revista de Biología Tropical, 47, 351-358.

[32] Encina-Domínguez, J.A. and Villareal-Quintanilla, J.A. (2002) Distribución y aspectos ecológicos del género Quercus (Fagaceae) en el estado de Coahuila, México. Polibotánica, 13, 1-23.

[33] de Souza, I.F., Sousa, A.F., Pizo, M.A. and Ganade, G. (2010) Using Tree Population Size Structures to Assess the Impacts of Cattle Grazing and Eucalypts Plantations in Subtropical South America. Biodiversity and Conservation, 19, 1683-1698. http://dx.doi.org/10.1007/s10531-010-9796-y

[34] Wadt, L.H.O., Kainer, K.A. and Gomes-Silva, D.A.P. (2005) Population Structure and Nut Yield of a Bertholletia excelsa Stand in Southwestern Amazonia. Forest Ecology and Management, 211, 371-384. http://dx.doi.org/10.1016/j.foreco.2005.02.061

[35] Souza, A.F. (2007) Ecological Interpretation of Multiple Population Size Structures in Trees: The Case of Araucaria angustifolia in South America. Austral Ecology, 32, 524-533. http://dx.doi.org/10.1111/j.1442-9993.2007.01724.x

[36] Rao, P., Barik, S.K., Pandey, H.N. and Tripathi, R.S. (1990) Community Composition and Tree Population Structure in a Sub-Tropical Broad-Leaved Forest along a Disturbance Gradient. Vegetatio, 88, 151-162. http://dx.doi.org/10.1007/BF00044832

[37] Cuevas-Guzmán, R., García-Moya, E. and Vázquez-García, J.A. (2008) Estructura poblacional y relaciones ambientales del árbol tropical Nectandra rudis (Lauraceae), una especie rara en el occidente de México. Revista de Biología Tropical, 56, 247-256.

[38] Soto, A., Lorenzo, Z. and Gil, L. (2007) Differences in Fine-Scale Genetic Structure and Dispersal in Quercus ilex L. and Q. suber L.: Consequences for Regeneration of Mediterranean Open Woods. Heredity, 99, 601-607. http://dx.doi.org/10.1038/sj.hdy.6801007

[39] Dostálek, J., Frantík, T. and Lukásová, M. (2011) Genetic Differences within Natural and Planted Stands of Quercus petraea. Central European Journal of Biology, 6, 597-605. http://dx.doi.org/10.2478/s11535-011-0034-8

[40] Fernández-M, J. and Sork, V.L. (2007) Genetic Variation in Fragmented Forest Stands of the Andean Oak Quercus humboldtii Bonpl. (Fagaceae). Biotropica, 39, 72-78. http://dx.doi.org/10.1111/j.1744-7429.2006.00217.x

[41] Aldrich, P.R., Parker, G.R., Michler, C.H. and Romero-Severson, J. (2003) Whole-Tree Silvic Identifications and the Microsatellite Genetic Structure of a Red Oak Species Complex in an Indiana Old-Growth Forest. Canadian Journal of Forest Research, 33, 2228-2237. http://dx.doi.org/10.1139/x03-160

[42] Peñaloza-Ramírez, J.M., Gonzalez-Rodriguez, A., Mendoza-Cuenca, L., Caron, H., Kremer, A. and Oyama, K. (2010) Interspecific Gene Flow in a Multispecies Oak Hybrid Zone in the Sierra Tarahumara of Mexico. Annals of Botany, 105, 389-399. http://dx.doi.org/10.1093/aob/mcp301

[43] Weiser, E.L., Grueber, C.E. and Jamieson, I.G. (2013) Simulating Retention of Rare Alleles in Small Populations to Assess Management Options for Species with Different Life Histories. Conservation Biology, 27, 335-344. http://dx.doi.org/10.1111/cobi.12011

[44] Molina-Garay, C. (2011) Diversidad genética y estructura poblacional de Quercus macdougallii, Encino endémico de Oaxaca, México. B.Sc. Thesis, Universidad Nacional Autónoma de México, México D.F.

[45] Pingarroni, A.A.M. (2011) Variabilidad y estructura genetic poblacional de Quercus mulleri (Fagaceae) encino endémico de la Sierra Sur de Oaxaca, México. B.Sc. Thesis, Universidad Nacional Autónoma de México, México D.F.

[46] Streiff, R., Ducousso, A., Lexer, C., Steinkellner, H., Gloessl, J. and Kremer, A. (1999) Pollen Dispersal Inferred from Paternity Analysis in a Mixed Oak Stand of Quercus robur L. and Q. petraea (Matt.) Liebl. Molecular Ecology, 8, 831-841. http://dx.doi.org/10.1046/j.1365-294X.1999.00637.x

[47] SEMARNAT-Secretaría de Medioambiente y Recursos Naturales (2010) Norma Oficial Mexicana NOM-059SEMARNAT-2010. Diario Oficial de la Federación (DOF).

[48] Allen, C.D., Macalady, A.K., Chenchouni, H., Bachelet, D., McDowell, N., Vennetier, M., Kizberger, T., Rigling, A., Breshears, D.D., Hogg, E.H., Gonzalez, P., Fensham, R., Zhang, Z., Castro, J., Demidova, N., Lim, J.H., Allard, G., 
Running, S.W., Semerci, A. and Cobb, N. (2010) A Global Overview of Drought and Heat-Induced Tree Mortality Reveals Emerging Climate Change Risks for Forests. Forest Ecology and Management, 259, 660-684.

http://dx.doi.org/10.1016/j.foreco.2009.09.001 
Scientific Research Publishing (SCIRP) is one of the largest Open Access journal publishers. It is currently publishing more than 200 open access, online, peer-reviewed journals covering a wide range of academic disciplines. SCIRP serves the worldwide academic communities and contributes to the progress and application of science with its publication.

Other selected journals from SCIRP are listed as below. Submit your manuscript to us via either submit@scirp.org or Online Submission Portal.
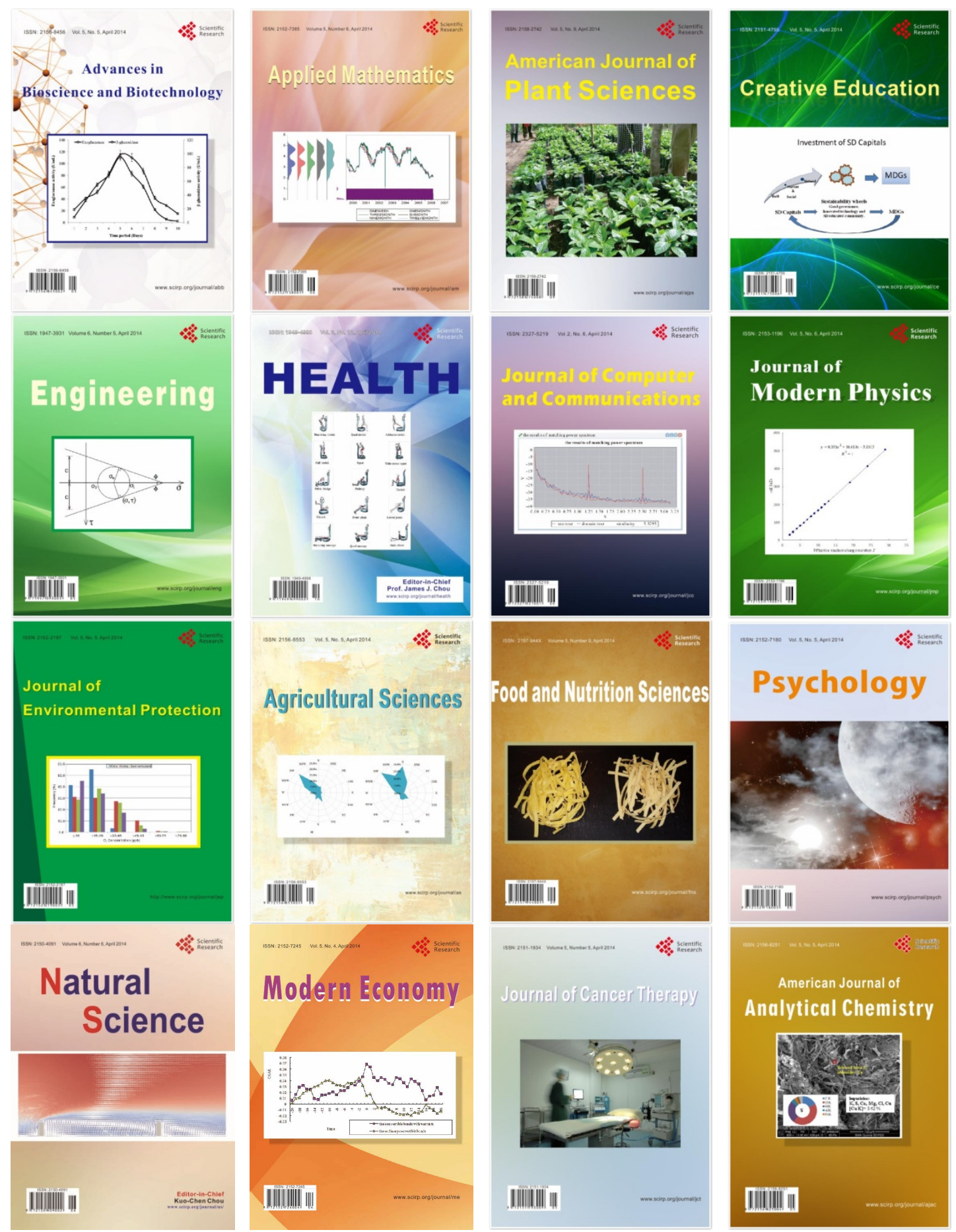